\title{
Role of TP53 polymorphisms in sub-Saharan mucosal cancers
}

\author{
Franco M Buonaguro", MariaLina Tornesello, Luigi Buonaguro \\ From $12^{\text {th }}$ International Conference on Malignancies in AIDS and Other Acquired Immunodeficiencies \\ (ICMAOI) \\ Bethesda, MD, USA. 26-27 April, 2010
}

\section{Background}

The most common TP53 gene polymorphism, which alters amino acid sequence of the oncosuppressor p53 protein, is located at the codon 72, resulting in either Pro72 or Arg72 p53 variant. Several studies have associated, with controversial results, the prevalence of the Arg allele with different types of cancer. The aim of this report is to analyze the role of p53 polymorphisms in two mucosal (conjunctival and genital) HPV-associated cancers during HIV epidemic.

\section{Distribution and role of TP53 Arg72 and Pro72 alleles in conjunctival neoplasia Method}

The study included 41 invasive conjunctival squamous cell carcinoma (ICSCC), 33 conjunctival intraepithelial neoplasia of grade 3 (CIN3), 33 of moderate grade (CIN1 and CIN2), and 115 controls from Uganda, a sub-Saharan country with the highest incidence rate of conjunctival neoplasia in the world, particularly in the era of AIDS.

\section{Results}

The TP53 Arg/Arg codon 72 genotype was detected in $21.9 \%$ of ICSCC and in $18.2 \%$ of CIN3 but only in $6 \%$ of CIN1-2 and in $5.2 \%$ of controls $(\mathrm{P}<0.05)$. These data show an increased risk of ICSCC (odds ratio $(\mathrm{OR})=6.2$, 95\% confidence interval (CI): 1.6-24.6) and CIN3 $(\mathrm{OR}=4.1,95 \%$ CI: 1.0-18.0) associated with TP53 Arg homozygosity, not observed in CIN1-2 lesions $(\mathrm{OR}=0.8$, 95\% CI: 0.1-5.1). Moreover, the frequency of the Arg homozygosity was similar in HIV-positive and HIVnegative groups.

\footnotetext{
*Correspondence: irccsvir@unina.it

Istituto Nazionale Tumori "Fondazione" Pascale," Naples, Italy

Full list of author information is available at the end of the article
}

\section{Discussion}

The results suggest that TP53 Arg/Arg codon 72 genotype is a relevant risk factor for invasive squamous cell carcinoma of the conjunctiva and for CIN3 in the Ugandan population.

\section{Distribution and role of TP53 Arg72 and Pro72 alleles in cervical neoplasia \\ Method}

In the genital mucosal study, 78 penile squamous cell carcinoma biopsies ( $\mathrm{n}=17$ from Uganda, $\mathrm{n}=61$ from Italy) and blood samples from 150 healthy controls $(\mathrm{n}=$ 57 from Uganda, $\mathrm{n}=93$ from Italy) have been analyzed for the arginine and proline allele distribution

\section{Results}

Among Ugandan cases the heterozygous, proline homozygous and arginine homozygous genotype frequency was $41.2 \%, 52.9 \%$, and $5.9 \%$, respectively, and among controls was $40.3 \%, 54.4 \%$, and $5.3 \%$, respectively $(\mathrm{P}=0.9917)$. Conversely, among Italian cases, genotype distribution was $42.6 \%, 4.9 \%$, and $52.5 \%$, and among controls was $34.4 \%, 7.5 \%$, and $58.1 \%$, respectively $(\mathrm{P}=0.5343)$.

\section{Discussion}

No significant differences in arginine and proline allele distribution were observed when the cases were stratified by HPV status. Therefore, no evidence of association between homozygosity for p53 arginine and HPV-related or HPV-unrelated penile squamous cell carcinoma was observed.

\section{Conclusions}

The overall results from the combined data of these studies strongly suggest that (1) Arg homozygosity represents 
a relevant risk factor for low-risk HPV $\beta$-related cancers, for which further co-carcinogenic factors are needed. (2) Arg homozygosity does not represent a significant risk factor for high-risk HPV $\alpha$-related cancers, such as penile cancers.

\section{Acknowledgements}

This article has been published as part of Infectious Agents and Cancer Volume 5 Supplement 1, 2010: Proceedings of the $12^{\text {th }}$ International Conference on Malignancies in AIDS and Other Acquired Immunodeficiencies (ICMAOI). The full contents of the supplement are available online at http://www.biomedcentral.com/1750-9378/5?issue=S1.

Published: 11 October 2010

doi:10.1186/1750-9378-5-S1-A73

Cite this article as: Buonaguro et al:: Role of TP53 polymorphisms in sub-Saharan mucosal cancers. Infectious Agents and Cancer 2010 5(Suppl 1):A73.

Submit your next manuscript to BioMed Central and take full advantage of:

- Convenient online submission

- Thorough peer review

- No space constraints or color figure charges

- Immediate publication on acceptance

- Inclusion in PubMed, CAS, Scopus and Google Scholar

- Research which is freely available for redistribution

Submit your manuscript at www.biomedcentral.com/submit 